\section{Bone Marrow Aplasia after Infectious Hepatitis Treated by Bone Marrow Transplantation}

\section{Royal Marsden Hospital Bone Marrow Transplant Team}

\section{British Medical fournal, 1974, 1, 363-364}

Bone marrow cells can now be transplanted for conditions other than immunity deficiency with a real hope of success. We report here the first such case in Britain with a complete long-term take of a bone marrow graft.

\section{Case Report}

A previously healthy 7 -year-old boy became anorexic and jaundiced in April 1973 (plasma bilirubin $9.5 \mathrm{mg} / 100 \mathrm{ml}$, alkaline phosphatase 35 K.A. U/100 ml, serum alanine transaminase $400 \mathrm{IU} / 1$, , serum aspartate transaminase $1,020 \mathrm{IU} / 1$.). He recovered his appetite in two weeks and the jaundice faded slowly. He then appeared to be in good health until in June, six weeks after the onset of the jaundice, he was found to bruise easily. A blood count showed pancytopenia, and aspiration and trephine biopsy showed the bone marrow to be hypocellular and fatty. Oxymetholone, prednisolone, and blood transfusion during the next six weeks produced no improvement and he was admitted to the Royal Marsden Hospital with a view to bone marrow transplantation.

HL-A typing of the family showed that one of his two sibs, a sister aged 13, was a suitable donor. She was phenotypically identical with the patient (table I) but since the mother was possibly homozygous for the HL-A 2,13 haplotype the question arose whether the sister was identical in HL-A genotype. The maternal grandparents were not available for typing but the results of $4 \mathrm{a} 4 \mathrm{~b}$ typing favoured the patient and his sister having inherited the same maternal HL-A haplotype. Mixed lymphocyte cultures (table II) confirmed the genetic identity so far as histocompatibility was concerned though the results were partly obscured by the low response of the patient's cells to phytohaemagglutinin (PHA) and foreign cells. This depressed response might have been attributable to the treatment with prednisolone or to disease.

TABLE I-HL-A Genotypes of the Patient and his Family

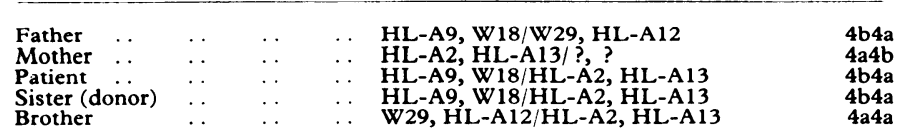

\section{Royal Marsden Hospital, London SW3 6JJ}

Members of the team were:

R. H. J. BEGENT, M.B., M.R.C.P., Medical Registrar, St. George's Hospital J. A. BIRCH, M.B., D.oBsT.R.C.O.G., House Physician, St. Bartholomew's Hospital

H. M. CLINK, M.B., M.R.C.PATH., Consultant Haematologist

A. HOCKLEY, F.I.M.L.T., Chief Technician

B. JAMESON, M.B., M.R.C.PATH., Consultant Microbiologist

H. E. M. KAY, F.R.C.P., F.R.C.PATH., Consultant Haematologist

P. T. KLOUDA, Prom. Biol., Lecturer, Institute of Cancer Research

S. D. LAWLER, M.R.C.P., F.R.C.PATH., Consultant Immunologist

D. N. LAWSON, M.D., F.R.C.P., Consultant Paediatrician

S. J. LYNCH, S.R.N., Sister in Charge of Isolation Ward

S. J. LYNCH, S.R.N., Sister in Charge of Isoletion Ward

T. J. MCELW WIN, M.B., M.R.C.P., Consultant Physician
R. L. POWLES, B.SC., M.R.C.P., Senior Scientific Officer, I.C.R.F. Department of Medical Oncology, St. Bartholomew's Hospital

J. A. RUSSELL, M.R.C.P., Senior Registrar

B. SUMMERSGILL, B.SC., Technician
TABLE II-Results of Tests with Mixed Lymphocyte Cultures (Average Counts per Minute)

\begin{tabular}{|c|c|c|c|c|c|c|}
\hline \multirow{2}{*}{ Stimulator } & & \multicolumn{5}{|c|}{ Responding Cells } \\
\hline & & Patient & Sister & Brother & Mother & Father \\
\hline $\begin{array}{ll}\text { Nil . } & . \\
\text { PHA } & \ldots \\
\text { Patient* } & \ldots \\
\text { Sister (donor) } \\
\text { Brother* } \\
\text { Mother* } & \ldots \\
\text { Father* } & \ldots \\
\end{array}$ & $\begin{array}{l}\ldots \\
\cdots \\
\cdots \\
\cdots \\
\cdots\end{array}$ & $\begin{array}{r}175 \\
1,862 \\
343 \\
375 \\
595 \\
213\end{array}$ & $\begin{array}{r}236 \\
10,577 \\
386\end{array}$ & $\begin{array}{r}546 \\
10,960 \\
2,538\end{array}$ & $\begin{array}{r}208 \\
36,023 \\
1,313\end{array}$ & $\begin{array}{r}114 \\
30,246 \\
388\end{array}$ \\
\hline
\end{tabular}

*Treated with mitomycin $C$.

All tests were done in triplica e. Figures are average counts $\left({ }^{3} \mathrm{H}\right.$-thymidine) per minute; $2 \times 10^{5}$ responding lymphocytes $/ \mathrm{ml}$ in TC-199 with $20^{\circ}{ }_{0}^{\circ} \mathrm{AB}$ serum.

The patient's general condition was good, with only minor bleeding phenomena and external otitis on the left. A swab from this yielded only Staphylococcus albus though he was a nasal carrier of Staph. aureus and the predominant organism in his mouth was Klebsiella pneumoniae. He was given ear-drops of chloramphenicol and gentamicin.

The procedure for the bone marrow transplantation (see fig.) followed strictly the Seattle protocol (Thomas and Storb, 1970).

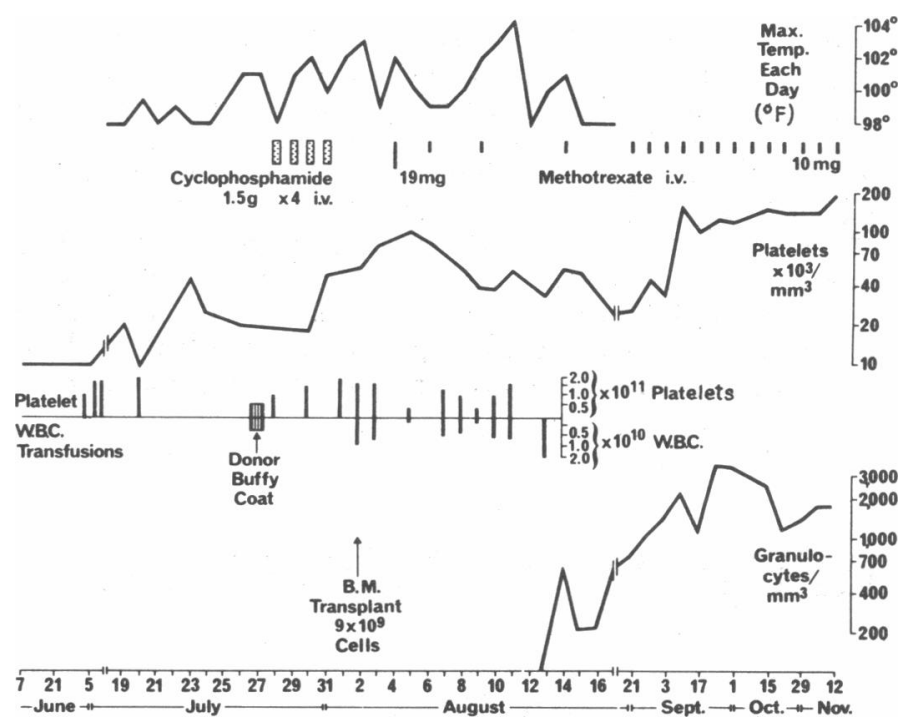

Clinical rourse and treatment before and after bone marrow transplantation.

Buffy coat cells from one unit of the donor's blood were given to the patient six days before operation and this was followed by cyclophosphamide $1.5 \mathrm{~g}$ intravenously on each of the four succeeding days (Santos, 1967). Bone marrow was obtained by multiple puncture of the iliac bones-also of the sternum and sacrum-a total of $9 \times 10^{9}$ cells being obtained in a volume of $160 \mathrm{ml}$ in one hour. This was devoid of fat and was infused intravenously directly via a transfusion set with filter. The donor had meanwhile received her own red cells and plasma stored from six days previously. Supportive therapy included isolation in a sterile environment and transfusions of platelets and leucocytes, mostly from a centrifugal separator (on one occasion a Leukopak system was used). In two weeks from the day of the transplantation nine donations from parents and unrelated donors yielded on average $9 \times 10^{9}$ leucocytes and $1.2 \times 10^{11}$ platelets. All these suspensions were irradiated to a total dose of 1,500 rads to suppress potential graft-against-host reactivity.

Immediately before transplantation and for 10 days thereafter the patient was febrile but at no time did he appear to be seriously ill. Because of the fever and the ear infection he was given intravenous gentamicin and later cephalothin for periods of 17 and 14 days 
respectively. Eight days after the operation the bone marrow contained a few myelocytes and normoblasts; on day 12 granulocytes reappeared in the blood stream and by day 18 the bone marrow showed definite signs of regeneration.

The success of the graft was monitored by chromosomal and serological analysis. No dividing cells could be found in a pretransplantation sample of bone marrow. A postoperative sample (20 August) yielded eight dividing cells, all of which were female. The donor was group $\mathrm{O}$ and the patient was group $\mathrm{A}$, other red cell antigens being obscured by previous transfusions. Analysis (6 November) three months after grafting showed that $80-90 \%$ of the patient's red cells were group $O$; by 131 days ( 11 December) no A cells could be found. There was also evidence of donor takeover in the lymphoid system. Lymphocyte cultures (10 August) stimulated with PHA yielded 24 dividing cells in which the sex could be determined; 21 were female and 3 were male. Lymphocyte cultures stimulated by pokeweed on the same day yielded two cells, one of each sex. By 17 September all cells in division after stimulation with PHA were female.

His subsequent progress was uneventful. His hair was rapidly regrowing and he was ready to resume a normal life, though for the coming winter at least he had to be protected from casual infections by viruses. His experience, including six weeks in isolation, seemed to have had no adverse effects; on the contrary, his mother said "it has brought him out-he is really articulate."

\section{Discussion}

The technique used to secure a permanent bone marrow graft in this case was developed by Thomas and his colleagues in Seattle (Thomas and Storb, 1970; Storb et al., 1974). In a series reported by Storb et al. (1974) 24 patients received grafts for hypoplasia of the bone marrow; 21 grafts, all from histocompatible siblings, were established but subsequent graft rejection or graft-against-host reaction reduced the survivors to 11. In this instance we were |fortunate that graft-against-host reaction was totally averted and that no treatment except the scheduled methotrexate was needed.

In four of the Seattle patients bone marrow aplasia had developed after infectious hepatitis and in one of these the bone marrow graft effected a long-term restoration of function. To this may be added another case of post-hepatitis aplasia in which transplantation was performed successfully by Camitta $e t$ al.
(1974), who also reviewed the literature on this relatively rare condition. Out of 76 patients only five spontaneously attained a complete remission and two others obtained a partial remission. Thus the mortality is about $90 \%$, so that the chance of recovery with a histocompatible graft (three out of six so far) represents an advance.

Thomas has stressed the importance of averting presensitization to minor histocomaptibility antigens by previous blood transfusion, especially with blood from donors who are related to the patient. Thus, once a diagnosis of severe aplastic anaemia has been made, an immediate priority is to discover whether there is a histocompatible sibling and to plan the treatment accordingly. In Britain the size of families is such that less than half of all patients will have such a sibling and, as yet, the prospects for using bone marrow from unrelated donors are not known. Secondly, if the existence of a histocompatible donor does encourage the attempt to graft it is vital to ensure that adequate supportive therapy, especially platelet transfusions and measures to guard against infection-isolation, granulocyte transfusions, or preferably both-can be provided.

Finally, there remains an ethical problem. Though the discomfort for the donor is slight and transient there is a risk, which is that of a general anaesthetic. With the whole family encamped nearby it was possible to explain the situation at leisure during the days while the mixed lymphocytes in culture were failing to react. In fact, our donor never hesitated and we felt that it was right to proceed, but it is a problem which will recur and has no simple solution.

We are indebted to Dr. H. Everley Jones for referring this case, to Dr. R. Storb for advice and encouragement, and, not least, to the marrow donor.

The report was drafted by Dr. H. E. M. Kay. Requests for reprints should be sent to him at the Royal Marsden Hospital, Fulham Road, London . SW3 6JJ.

\section{References}

Camitta, B. M., et al. (1974). Blood. In press.

Santos, G. W. (1967). Experimental Haematology, 14, 32.

Storb, R., et al. (1974). Blood. In press.

Thomas, E. D., and Storb, R. (1970). Blood, 36, 507.

\section{MEDICAL MEMORANDA}

\section{Apathetic T-3 Toxicosis}

\section{P. D. FAIRCLOUGH, G. M. BESSER}

British Medical fournal, 1973, 1, 364-365

Thyrotoxicosis may be clinically occult and may even present with apathy, in contrast to the more usual hyperdynamic syndrome (Lahey, 1931 a, 1931 b, 1932). "Triiodothyronine (T-3) toxicosis" is a biochemically occult form of hyperthyroidism in which the simple tests of thyroid function give normal results. We present a case of both clinically and biochemically "hidden hyperthyroidism" due to apathetic T-3 toxicosis.

\footnotetext{
Medical Professorial Unit, St. Bartholomew's Hospital, London EC1A 7BE

P. D. FAIRCLOUGH, M.B., M.R.C.P., Junior Registrar

G. M. BESSER, M.D., F.R.C.P., Senior Lecturer in Endocrinology
}

\section{Case Report}

A 43-year-old woman of Swiss-Italian origin was first seen at St. Bartholomew's Hospital in 1969 because of a nodule in the left lobe of the thyroid gland. In 1958 she had developed a diffuse goitre and heat intolerance and had lost weight. She was treated medically in Italy with apparent suocess. Her mother, who was from Interlaken, and three maternal aunts had required thyroidectomy for thyrotoxicosis. The patient complained of tiredness and malaise. On examination she had a puffy face, appeared slow and apathetic, and was thought to be clinically hypothyroid. P.B.I. was $5 \mu \mathrm{g} / 100 \mathrm{ml}$ (normal range $4-8 \mu \mathrm{g} / 100 \mathrm{ml}$ ). Radioiodine studies: scan showed single area of functioning thyroid tissue to the left of the midline; uptake was $22 \%$ of the administered dose at six hours, $32 \%$ at 24 hours, and $29 \%$ at 48 hours (normal maximum uptake $50 \%$ ). She was then lost to follow-up.

In 1971 she was again referred because of the thyroid nodule. She complained of tiredness and menorrhagia. Her physical appearance had not changed. Her pulse was $70 / \mathrm{min}$ and the ankle jerk relaxation time was clinically normal. Two out of three clinicians who saw her thought that she was hypothyroid; the third refused to commit himself. She was given thyroxine $300 \mu \mathrm{g}$ daily on clinical grounds and to suppress the goitre. After two months on thyroxine she had lost $4 \mathrm{~kg}$ in weight and was hyperactive, 